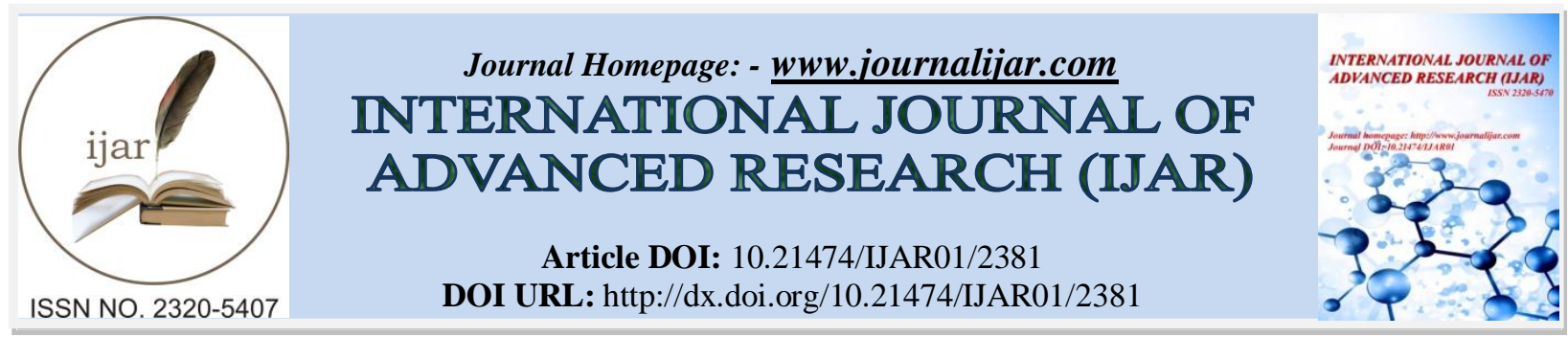

RESEARCH ARTICLE

\title{
NEURAL TISSUE ENGINEERING.
}

Salonika Aggarwal and Vipul Kumar.

M. Tech, Department of Paper Technology, IIT Roorkee.

\section{Manuscript Info}

Manuscript History

Received: 19 October 2016

Final Accepted: 20 November 2016

Published: December 2016

\section{Abstract}

Various problems and complications arise while doing treatment of severe nerve injuries with conventional methods such as Autologous Nerve Grafting, Allograft and Xenografts. Recent advancements in nerve regeneration have involved the application of tissue engineering principles and this has evolved a new perspective to neural therapy. Tissue Engineering (TE) basically makes use of a combination of cells, growth factors and scaffolds to improve or replace injured tissues. Scaffolds are basically analogous to ECM (Extra Cellular Matrix) and it can support 3D growth of nerve or any other cell type. An ideal scaffold is biocompatible, less inflammatory, doesn't produce toxic degradation products and porous (for vascularization and cell migration). This review paper is about the various principles required for fabrication of scaffold for neural tissue engineering.

Copy Right, IJAR, 2016,. All rights reserved.

\section{Introduction:-}

Human brain is just like black box of an airplane. It has so many processing centers which are required for proper functioning of life activities. Unit of human brain is nerve cell. So for the treatment of any neural disorder or neural damage we will have to concentrate on the repairing of nerve cell. There is a technique called Autologous Nerve Graft for repairing of neural damage. This techniques is also called "gold standard for repairing nerve damage"(1). This is not a perfect treatment because the final outcome is only limited function recovery. It also requires multiple surgeries to harvest the tissue and to implant it. Other treatment strategies include Allograft and Xenografts. In allograft, the tissue for graft is taken from another person while in xenograft, tissues are taken from any other species. Both allografts and xenografts have same disadvantages as autografts, but additional problem here is tissue rejection from immune response(2).

These disadvantages can be solved with the help of Tissue Engineering (TE)(3). TE basically makes use of a combination of cells, growth factors and scaffolds to improve or replace injured tissues. Scaffold is one of the most important elements of TE. Scaffold, a 3D porous architecture consisting of various biomaterials, acts as a temporary platform for the growth of cells. An ideal scaffold should be biocompatible, less inflammatory, and doesn't produce toxic degradation products. It must be porous for vascularization and cell migration(4). Scaffolds are in general made of various types of synthetic and natural polymers, such as PGA (Poly(glycolic acid)), PLA (poly (lactic acid), PLGA (Poly (lactic acid-co-glycolic acid)), PCL (poly(caprolactone)), PHB (poly hydroxybutyrate), collagen, gelatin, alginate, silk etc.(5). There are various methods for scaffold fabrication e.g. electro spinning, phase separation, freeze drying, self assembly etc.(6). 


\section{How nerve cells repair themselves?}

Nerve cells are able to repair the damage of $6 \mathrm{~mm}$ (7). If size of nerve damage is more than that of $6 \mathrm{~mm}$ size than it become difficult to repair nerve damage and it is still a challenge. Figure 1(8) is showing the various events which took place during nerve regeneration. After division of the same single nerve fiber, Wallerian degeneration occurs. The single nerve fiber will "sprout" to form a regenerating unit. As the regenerating unit matures, the individual sprouts and become myelinated. Basal lamina adjacent to this regenerating unit represents an area of degeneration without regeneration (Bands of Bungner).
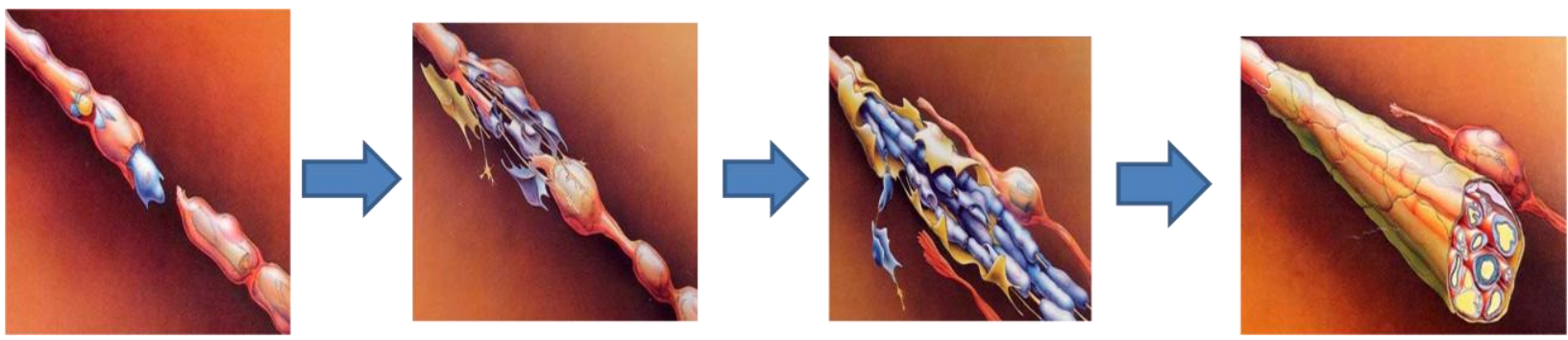

Figure 1:- Various events taking place after nerve degeneration.

If we can enhance the activity of Band of Bungner, then it will ease the process of nerve repairing. Many strategies have been attempted to improve the regenerative potency of neurons such as cell therapy, exogenous delivery of growth factors and tissue engineering approaches; each in turn restores the function with varying degrees of success. Schwann cells have capability of neural regeneration and remyelination. They perform this function by secreting adhesion molecules L1 and neural cell adhesion molecule (N-CAM), extracellular molecules(collagen and laminin) and a number of tropic factors such as nerve growth factor (NGF), brain-derived neurotrophic factor (BDNF) and neurotrophin-3 (NT-3) (9).

\section{Scaffolds and their possible role in neural cell repairing:-}

The differentiation of neural stem cells can be controlled by constructing scaffolds of composite biomaterials that have similar properties as that of extracellular matrix (ECM) (10). Stem cells have capability to differentiate in any type of cell; and these stem cells can be proliferated and differentiated in scaffold made up of fibrin like structure (11). Astrocytes help in development of neural cell or neuro-genesis from stem cell(12). So we can grow astrocytes on polymeric substance for neurogenesis(13). OEC (Olfactory Ensheathing Cells) also have similar properties like that of Astrocytes cell, so OEC can also be used for neural regeneration (14).

Growing stem cell on polymeric surface seems to be easier but actually it is not so. In this process it is very difficult to control cell proliferation as well as to maintain 3D structure of cells (15). If we provide various bioactive factors such as NGFs (Neural Growth Factors) to stem cells used in neural tissue engineering then growth of implanted cells on polymer can be increased (16). These NGFs can be make to reach to target stem cell by making use of guidance channels or conduits (17). Various unanswered questions in stem cell-based therapy such as carcinogenicity and ethical concerns helps in limiting their use. Electrospun nanofibrous scaffold have become a successful, popular and safe vehicle for delivery of bioactive growth factors and it can simultaneously act as a scaffold also (18).

\section{Materials for scaffold fabrication:-}

Various natural polymers (e.g. chitosan, chitin, collagen, gelatin, alginate), synthetic polymers which are nonbiodegradable (e.g. silicone), synthetic biodegradable polymers (e.g. PLGA, poly ( $\varepsilon$-caprolactone (PCL), poly Llactic acid (PLLA)) and conducting polymers (e.g. polypyrrole, polyaniline) have been used for scaffold fabrication for neural tissue engineering. Whatever material is used for scaffold fabrication but in the end fabricated scaffold must be thin, biocompatible, porous, biodegradable, biocompatible and inductive in nature, otherwise fabricated scaffold will be of no use. It should also have appropriate mechanical strength as well as flexibility. It should be pliable and harmless to surrounding tissues. It should also be capable of avoiding structural collapse during implantation (20). Surface erosion of scaffold is also required for ensuring its long life, because if bulk erosion is taking place then life of scaffold will be small (19). 


\section{How to increase cell adhesion properties of scaffold?}

Three dimensional tissue culture is important because it increases cell-cell interaction and which in turn improves regeneration of the injured tissue (21). All these will happen only and only if cells are in proper attachment with scaffold. Proper attachment of cells with scaffold requires good cell adhesion properties of scaffold.Cell adhesion property is a must requirement for any scaffold because if cell will not adhere to scaffold then cell proliferation and differentiation will be a tedious task. Cell adhesion property of a scaffold mainly depends on its surface characteristics such as charge density and wettability (22). Most of the polymers used in scaffold fabrication are hydrophobic in nature and that's why their adhesive properties are poor. We can improve their adhesion properties by using ECM (Extracellular Matrix) materials such as laminin, fibronectin, collagen etc (23). All these are basically proteins and when they are coated on surface of scaffold then adhesive properties of scaffold is improved which in turn increases the cell adhesion property. Beside these we can also incorporate specific adhesion peptide sequences like RGD and IKVAV, YIGSR. They induce hydrophilicity which in turn improves the cell adhesion property of the scaffold.

What are the available techniques for scaffold fabrication?

There are different scaffold fabrication techniques such as solvent casting, particulate leaching, melt molding etc., to fabricate scaffolds of various geometries with the desired porosity and surface area for cell scaffolding (24). Scaffolds made up of nanofibers, sintered matrix, nanofoams, hydrogels, nanotubes, etc., have been extensively used as a scaffold in neural regeneration.

\begin{tabular}{|c|c|c|c|}
\hline S. No. & Biomaterials & $\begin{array}{l}\text { Modification/Method of } \\
\text { fabrication }\end{array}$ & Improved Properties \\
\hline 1 & $\begin{array}{l}\text { Star-Poly(ethylene } \\
\text { glycol) }\end{array}$ & $\begin{array}{l}\text { Incorporation of } \\
\text { polysaccharide (Heparin) }\end{array}$ & $\begin{array}{l}\text { Tunable physical and mechanical properties to } \\
\text { adopt specific tissue requirements }\end{array}$ \\
\hline 2 & Chitosan & $\begin{array}{l}\text { Modified with }(\gamma- \\
\text { glycidoxypropyltrimethoxys } \\
\text { ilane } \\
(\text { GPTMS })\end{array}$ & Mechanical strength \\
\hline 3 & Poly(sialic acid) & $\begin{array}{l}\text { Hydrogel modified with } \\
\text { adsorbed poly-L-lysine or } \\
\text { poly-L-ornithine or laminin } \\
\text { or collagen }\end{array}$ & Mechano compatibility; Cell adhesive property \\
\hline 4 & $\begin{array}{l}\text { Poly }(\beta- \\
\text { hydroxybutyrate })\end{array}$ & $\begin{array}{l}\text { Sheets impregnated with } \\
\text { extracellular matrix } \\
\text { Molecules }\end{array}$ & Cell adhesion and proliferation \\
\hline 5 & Poly( $\varepsilon$-caprolactone $)$ & $\begin{array}{l}\text { Electrospinning and } \\
\text { Thermal fiber bonding }\end{array}$ & Mechanical strength \\
\hline 6 & Poly( $\varepsilon$-caprolactone $)$ & $\begin{array}{l}\text { Aligned fibers by } \\
\text { Electrospinning }\end{array}$ & Contact guidance \\
\hline 7 & $\begin{array}{l}\text { Poly(lactic-co- } \\
\text { glycolic acid) }\end{array}$ & $\begin{array}{l}\text { Modified immersion } \\
\text { precipitation method }\end{array}$ & Selective permeability; Hydrophilicity \\
\hline 8 & $\begin{array}{l}\text { Poly(D, L-lactide- } \\
\text { co- } \varepsilon^{-} \\
\text {caprolactone }) \\
{[\text { PDLLA/CL] }}\end{array}$ & $\begin{array}{l}\text { PPy coating substrate and } \\
\text { PPy nanoparticle/PDLLA/ } \\
\text { CL composite }\end{array}$ & Electrical cue for multitude of cell functions \\
\hline 9 & Chitosan & $\begin{array}{l}\text { Polylysine-functionalised } \\
\text { thermoresponsive } \\
\text { chitosan hydrogel }\end{array}$ & $\begin{array}{l}\text { Injectable scaffold; Mechano compatibility; } \\
\text { Surface property (wettability, charge density) }\end{array}$ \\
\hline 10 & Poly( $\varepsilon$-caprolactone $)$ & $\begin{array}{l}\text { Electrospinning (Polymer } \\
\text { blending with collagen) }\end{array}$ & $\begin{array}{l}\text { Biological property (schwann cell adhesion, } \\
\text { migration and differentiation) }\end{array}$ \\
\hline 11 & Collagen & $\begin{array}{l}\text { Hydrogel crosslinked with } \\
\text { YIGSR peptide modified } \\
\text { Dendrimers }\end{array}$ & $\begin{array}{l}\text { Biological function } \\
\text { (promote the growth of corneal epithelial cells and } \\
\text { neurite outgrowth) }\end{array}$ \\
\hline 12 & $\begin{array}{l}\text { Poly(glycerol- } \\
\text { sebacate) }\end{array}$ & Replica molding & $\begin{array}{l}\text { Micropatterned substrates; Flexibility; Surface } \\
\text { degradable; Strong contact guidance response }\end{array}$ \\
\hline 13 & $\begin{array}{l}\text { Poly(lactic-co- } \\
\text { glycolic acid) }\end{array}$ & Microbraiding method & Flexibility; Porosity \\
\hline 14 & $\begin{array}{l}\text { Poly(D,L-lactide-co- } \\
\text { glycolide) }\end{array}$ & $\begin{array}{l}\text { Low pressure injection } \\
\text { molding }\end{array}$ & $\begin{array}{l}\text { Porosity; Longitudinally aligned channels; Mimigro } \\
\text { the geometry of native nerves }\end{array}$ \\
\hline
\end{tabular}


Various approaches have been attempted to improve the properties of common biomaterials to make scaffold suitable for neural tissue engineering. Table 1 (25) is showing a list of biomaterials, their method of fabrication and their improved properties. All these tabulated materials have been used in neural tissue engineering.

\section{Electrospinning Technology for nanofibres fabrication:-}

Substrate is the essential requirement forfor tissue engingineering because it provides an attachment site for cells. Without attachment site the scaffold will be of no use. Nano fibres resemples ECM (Extra Cellular Matrix) and that's why they provide a suitable site for attachment to cell (26). Diameter of nanofibres is less than 1 micron. Nano fibres have high surface are to volume ratio and they also have very high mechanical strength. Both of these properties are must required for neural tissue engineering (27). Electro-spinning is the easiest method to fabricate nanofibres. Aligned nanofibres support proper orientation of cell in scaffold and they also improve neurite outgrowth with proper differentiation of neural cell (28). The parameters such as viscosity, conductivity, surface tension of polymer solution, applied electric potential, flow rate, and distance between the electrodes are to be optimized while carrying on the electrospinning process (29).

\section{Role of electrical stimulation in neural tissue engineering:-}

Neural cells communicate through generating action potential at their synapse. Generating action potential is a type of electrical stimulation. So we can say say that electrical stimulation play an important role in neural communication. So a scaffold which is going to be used for neural tissue engineering must have conducting polymer so that electrical stimulation can easily be pass through scaffold, which in turn will be responsible for better neurite outgrowth. Polypyrrole (Ppy), is a conducting polymer and it is used in biomedical applications. It has capability to enhance the nerve regeneration by electrical stimulation (30). Beside showing conductivity, Polypyrrole does not produce any type of anti-oxidant (31), so it is biocompatible, which is its further advantage. Both of these properties make it a suitable material for scaffold fabrication for neural tissue engineering. Cell adhesion property of polypyrrole can be improved by chemical conjugation of carboxylic acid group with RGD peptide (32).

\section{Future of neural tissue engineering:-}

Neural Tissue Engineering is providing a promising method for neural regeneration, but this area is still not fully explored. Long term effects of usage of polymers on human heath is still to be find out. Treatment of neurological disrorders with the help of neural tissue engineering is still to be done.

\section{Conclusion:-}

An ideal nerve scaffold must be porous, biocompatible, biodegradable, neuroconductive, neuroinductive, infection resistant, properly aligned, incapable of producing antioxidants and should mimic the ECM. Electrospinning is an easier method to produce nanofibrous scaffold with all these desirable properties for neural tissue engineering. Conducting polymers like polypyrrole, polyaniline etc., having conducting properties that's why they can be used for enhancing and stimulating neurite extension in scaffold. No single polymer can have all the desirable properties for fabricating ideal scaffold for neural tissue engineering, so this field is still wide open design the most appropriate polymer scaffold with all the desirable properties andvital conditions for effective neural applications in vivo.

\section{References:-}

1. Chimutengwende-Gordon Mukai, Khan Wasim; Recent Advances and Developments in Neural Repair and Regeneration for Hand Surgery, The Open Orthopaedics Journal, 2012, 6, (Suppl 1: M13) 103-107.

2. Jacobsen Garth, Easter David; Allograft vs. Xenograft-Practical Considerations for Biologic Scaffolds, 2009.

3. E. Teebken Omke; Graft, january/february 2002, volume 5, issue 1, 15.

4. Chan B. P., Leong K. W. ; Scaffolding in tissue engineering: general approaches and tissue-specific considerations, 13 November 2008, (Suppl 4):S467-S479.

5. M. Willerth Stephanie, E. Sakiyama Shelly-Elbert; Approaches to neural tissue engineering using scaffolds for drug delivery, 10 April 2007, Advanced Drug Delivery Reviews 59 (2007) 325-338.

6. Lu Tingli,Yuhui Li1, Tao Chen; Techniques for fabrication and construction of three-dimensional scaffolds for tissue engineering, International Journal of Nanomedicine 2013:8 337-350.

7. Haile Y, Haastert K, Cesnulevicius K, Stummeyer K, Timmer M, Berski S, Drager G, Gerardy-Schahn R, Grothe C: Culturing of glial and neuronal cells on polysialic acid. Biomaterials 2007, 28:1163-1173.

8. Wallerian Degeneration from the textbook Surgery of the Peripheral Nerve by Susan E. Mackinnon, A. Lee Dellon. 
9. J. Rodrı'guez Francisco, Verdu' Enrique, Ceballos Dolores, Navarro Xavier; Nerve Guides Seeded with Autologous Schwann Cells Improve Nerve Regeneration, 2000, Experimental Neurology 161, 571-584.

10. Nakajima M, Ishimuro T, Kato K, Ko IK, Hirata I, Arima Y, Iwata H: Combinatorial protein display for the cellbased screening of biomaterials that direct neural stem cell differentiation. Biomaterials 2007, 28:1048-1060.

11. Johnson Philip J., Parker Stanley R., and Sakiyama-Elbert Shelly E. ; Fibrin-based tissue engineering scaffolds enhance neural fiber sprouting and delays the accumulation of reactive astrocytes at the lesion in a subacute model of spinal cord injury, J Biomed Mater Res A. 2010 January ; 92(1): 152-163.

12. Phillips Melissa Lee; Astrocytes and Neurogenesis, Neuroscience for Kids Consultant May 21, 2002.

13. Jung Sang-Myung, Kim Sung Hoon, Min Seul Ki, Shin Hwa Sung; Controlled activity of mouse astrocytes on electrospun PCL nanofiber containing polysaccharides from brown seaweed, In Vitro Cell.Dev.Biol.-Animal (2012) 48:633-640.

14. Lakatos Andras, Barnett Susan C, Franklina Robin J.M.; Olfactory ensheathing cells induce less host astrocyte response and chondroitin sulphate proteoglycan expression than Schwann cells following transplantation into adult CNS white matter, Experimental Neurology 184 (2003) 237-246.

15. Levenberg S, Huang NF, Lavik E, Rogers AB, Itskovitz-Eldor J, Langer R: Differentiation of human embryonic stem cells on threedimensional polymer scaffolds. PNAS 2003, 100:12741-12746.

16. Aloe Luigi, Rocco Maria Luisa, Bianchi Patrizia, Manni Luigi; Nerve growth factor: from the early discoveries to the potential clinical use, Aloe et al. Journal of Translational Medicine 2012, 10:239.

17. Belkas Jason S., Shoichet Molly S., Midha Rajiv; Axonal Guidance Channels in Peripheral Nerve Regeneration, 2004 Elsevier Inc. 2004.06.001.

18. Haoqing C, Ting L, Sing YC: The application of nanofibrous scaffolds in neural tissue engineering. Advanced Drug Delivery Reviews 2009, 61:1055-1064.

19. Sundback CA, Shyu JY, Wang Y, Faquin WC, Langer RS, Vacanti JP, Hadlock TA: Biocompatibility analysis of poly(glycerol sebacate) as a nerve guide material. Biomaterials 2005, 26:5454-5464.

20. Chan B. P. , Leong K. W.; Scaffolding in tissue engineering: general approaches and tissue-specific considerations, Eur Spine J (2008) 17 (Suppl 4):S467-S479.

21. Huh Dongeun, Hamilton Geraldine A., Ingber Donald E.; From 3D cell culture to organs-on-chips, Trends in Cell Biology, December 2011, Vol. 21, No. 12.

22. Lee J, Cuddihy MJ, Kotov NA: Three-dimensional cell culture Matrices: State of the Art. Tissue engineering Part B 2008, 14:61-86.

23. Baker Brendon M., Handorf Andrew M., Ionescu Lara C., Li Wan-Ju, Mauck Robert L.; New Directions in Nanofibrous Scaffolds for Soft Tissue Engineering and Regeneration, Expert Rev Med Devices. 2009 September ; 6(5): 515-532.

24. Boland ED, Espy PG, Bowlin GL: Enycyclopedia of Biomaterials and Biomedial Engineering. In Tissue Engineering Scaffolds Volume 2nd edition. Edited by: Wnek GE, Bowlin GL. New York: Informa Healthcare USA, Inc; 2008:2828-2837

25. Subramanian Anuradha, Maheswari Krishnan Uma, Swaminathan Sethuraman; Development of biomaterial scaffold for nerve tissue engineering:Biomaterial mediated neural regeneration, Journal of Biomedical Science 2009, 16:108.

26. Vasita Rajesh, Katti Dhirendra S; Nanofibers and their applications in tissue engineering, International Journal of Nanomedicine 2006:1(1) 15-30.

27. Zhnag Shu; Mechanical and Physical Properties of Electrospun Nanofibers, thesis submitted to the Graduate Faculty of North Carolina State University, August 7, 2009.

28. Shang Shuhuan, Yang Fang, Cheng Xiangrong, Walboomers X. Frank, Jansen John A.; The effect of electrospun fibre alignment on the behaviour of Rat periodontal ligament cells, European Cells and Materials Vol. 192010 (pages 180-192).

29. Ji Y, Ghosh K, Shu XZ, Li B, Sokolov JC, Prestwich GD, Clark RA, Rafailovich MH: Electrospun three-dimensional hyaluronic acid nanofibrous scaffolds. Biomaterials 2006, 27:3782-3792.

30. Leea Jae Y., Bashur Chris A., Goldsteinb Aaron S., Schmidt Christine E.; Polypyrrole-coated electrospun PLGA nanofibers for neural tissue applications, Biomaterials 30 (2009) 4325-4335.

31. Durgam H, Sapp S, Deister C, Khaing Z, Chang E, Luebben S, Schmidt CE; Novel degradable co-polymers of polypyrrole support cell proliferation and enhance neurite out-growth with electrical stimulation, J Biomater Sci Polym Ed. 2010;21(10):1265-82.

32. Gomez Natalia,. Schmid Christine E; Nerve growth factor-immobilized polypyrrole: Bioactive electrically conducting polymer for enhanced neurite extension, J Biomed Mater Res A. 2007 April ; 81(1): 135-149. 